\title{
38. SUMMARY OF CRETACEOUS/TERTIARY BOUNDARY STUDIES, DEEP SEA DRILLING PROJECT SITE 577, SHATSKY RISE ${ }^{1}$
}

\author{
Audrey A. Wright, Ulrich Bleil, Simonetta Monechi, Helen V. Michel, N. J. Shackleton, Bernd R. T. Simoneit, and \\ James C. Zachos ${ }^{2}$
}

\begin{abstract}
Continuous, expanded, and undisturbed Cretaceous/Tertiary boundary sequences were recovered in three holes drilled at Deep Sea Drilling Project Site $577\left(32^{\circ} 26.51^{\prime} \mathrm{N}, 157^{\circ} 43.40^{\prime} \mathrm{E}\right)$ on Shatsky Rise. The Cretaceous/Tertiary boundary lies at a sub-bottom depth of approximately $109.6 \mathrm{~m}$ in a white calcareous ooze. It was identified biostratigraphically within the magnetic C-29R subchron using nannofossils and is characterized by an iridium anomaly of $61 \mathrm{ng} / \mathrm{cm}^{2}$ and a sharp $1 \%$ decrease in ${ }^{13} \mathrm{C}$. Limited organic geochemical samples suggest that molecular stratigraphy cannot be applied definitively across the boundary.
\end{abstract}

\section{INTRODUCTION}

Deep Sea Drilling Project (DSDP) Site 577 is located at $32^{\circ} 26.51^{\prime} \mathrm{N}$ and $157^{\circ} 43.40^{\prime} \mathrm{E}$ in $2678 \mathrm{~m}$ of water on the flank of the Shatsky Rise, close to DSDP Site 47 (Fig. 1). Primary drilling objectives at Site 577 were to obtain a detailed paleoceanographic record for the western edge of the subtropical gyre during the late Neogene Period, to establish a high-resolution stratigraphy for the Neogene and Quaternary periods using paleomagnetics, stable isotopes, and biostratigraphy, and to recover the Cretaceous/Tertiary boundary for midlatitude calcareous biostratigraphic, paleomagnetic, and geochemical studies. Three holes were hydraulically piston cored at Site 577; two of them penetrated Quaternary to Upper Cretaceous sediments (Holes 577 and 577A) including Cretaceous/Tertiary boundary sequences. The third hole was washed to basal Paleocene sediments and a third Cretaceous/Tertiary boundary sequence was recovered, providing enough material for all the scientific studies of the boundary that were planned.

This summary chapter briefly details the primary results of shipboard and shore-based studies of the Site 577 Cretaceous/Tertiary boundary sequences. Other Site 577 results from shipboard investigations are given in the Site 577. chapter (this volume). Site 577 shore-based studies not focused on the Cretaceous/Tertiary boundary sequence include radiolarian biostratigraphy (Morley, this volume), diatom biostratigraphy (Koizumi and Tanimura, this volume), heat flow and thermal conductivity (Horai and Von Herzen, this volume), physical and geotechnical properties (Schultheiss, this volume), and interstitial water chemistry (McDuff, this volume).

\footnotetext{
${ }^{1}$ Heath, G. R., Burckle, L. H., et al., Init. Repts. DSDP, 86: Washington (U.S. Govt. Printing Office).

2 Addresses: (Wright) Ocean Drilling Program, Texas A\&M University, College Station, TX 77843; (Bleil) Institut für Geophysik, Ruhr-Universităt Bochum, Postfach 102148, D-4630 Bochum, Federal Republic of Germany; (Monechi) Dipartimento di Scienze della Terra, Università di Firenze, Via G. La Pira n. 4, 50121 Firenze, Italy; (Michel) Lawrence Berkeley Laboratory, University of California at Berkeley, Berkeley, CA 94720; (Shackleton) University of Cambridge, Godwin Laboratory for Quaternary Research, Free School Lane, Cambridge CB2 3RS, England; (Simoneit) College of Oceanography, Oregon State University, Corvallis, OR 97331; (Zachos) Graduate School of Oceanography, University of Rhode Island, Kingston, RI 02882.
}

\section{Site 577 Lithostratigraphy}

All of the sediments recovered at Site 577 are lightly mottled nannofossil oozes (Fig. 1), divided into three lithologic units on the basis of color variations.

Lithologic Unit I (0-53.5 m sub-bottom) is a white to light gray nannofossil ooze. It is divided into two subunits on the basis of a downcore decrease in the percentage of foraminifers, radiolarians, and diatoms. The upper subunit contains $60-95 \%$ nannofossils, with common foraminifers $(0-20 \%)$ and rare radiolarians $(0-7 \%)$ and diatoms (0-3\%). The lower subunit contains $90-97 \%$ nannofossils, only a few percent foraminifers, and traces of radiolarians and diatoms.

Lithologic Unit II (53.5-111.9 m sub-bottom) is a white to pale brown nannofossil ooze. It is divided into two subunits, the upper one being pale brown in color and containing $80-90 \%$ nannofossils and only trace amounts of foraminifers. The lower subunit is characterized by alternating white and pale brown colors, $65-$ $95 \%$ nannofossils, and $0-35 \%$ foraminifers.

Lithologic Unit III (111.9-123.4 m sub-bottom) is a white calcareous nannofossil ooze containing $80-90 \%$ nannofossils.

An undisturbed Cretaceous/Tertiary boundary has been located at a sub-bottom depth of $109.10 \mathrm{~m}$ in Hole 577 and $109.62 \mathrm{~m}$ in Holes 577A and 577B, in all cases within the lower subunit of Lithologic Unit II. Except for a minor color change from a Maestrichtian white to a Tertiary light brown calcareous ooze, the Cretaceous/ Tertiary boundary sediments are essentially featureless with no signs of sedimentation disruption (see frontispiece, this volume).

\section{BIOSTRATIGRAPHY OF THE CRETACEOUS/TERTIARY BOUNDARY}

Sediments recovered throughout Site 577 are rich in calcareous microfossils that provide a high-resolution late Cenozoic, Paleogene, and Upper Cretaceous biostratigraphy. Site 577 nannofossil stratigraphy is detailed in Monechi (this volume); results from the Cretaceous and lower Paleogene section close to the Cretaceous/Tertiary 


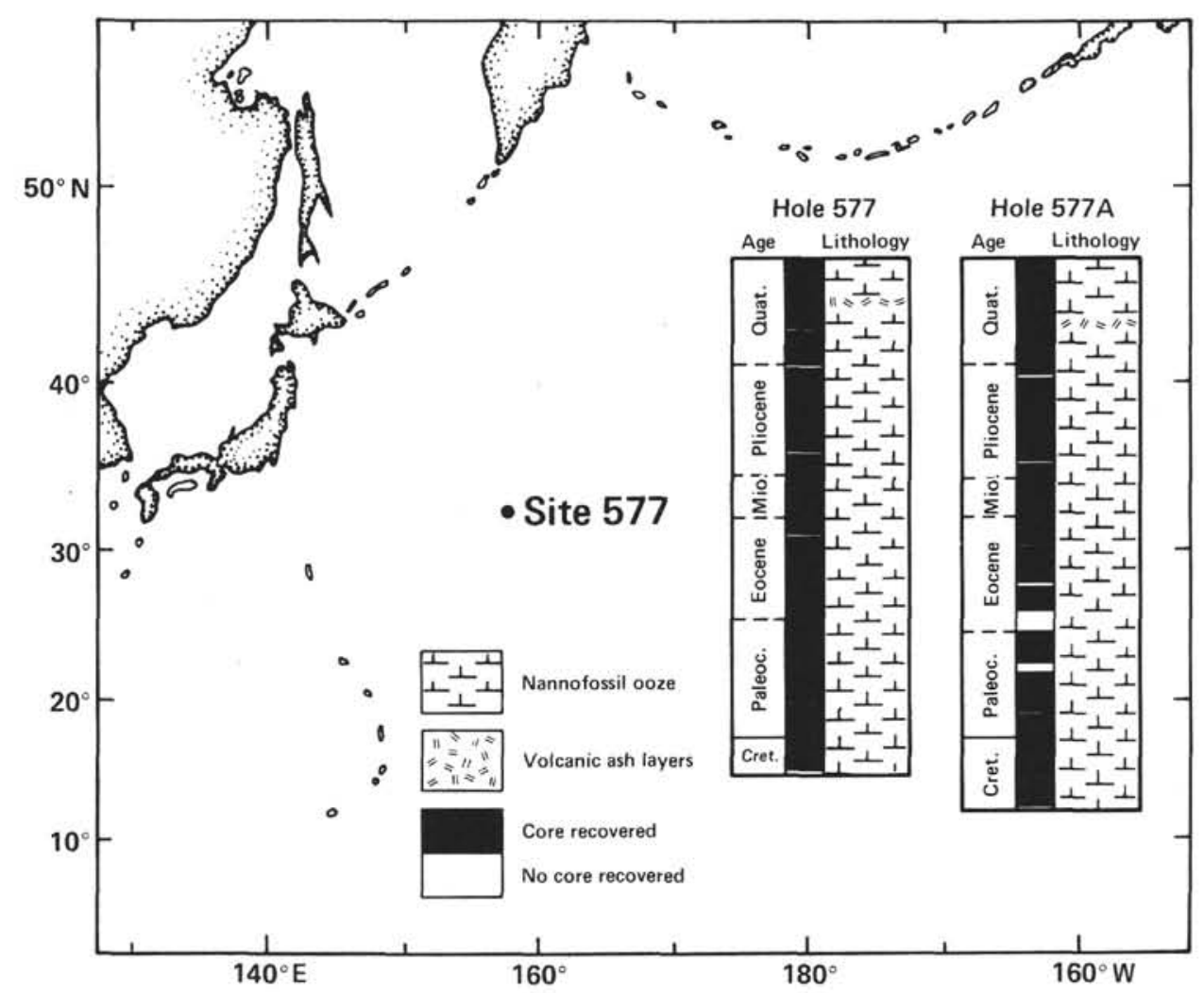

Figure 1. Location of Site 577 on the Shatsky Rise and generalized age, core recovery, and lithology of the sediments recovered in Holes 577 and 577A (from Monechi et al., this volume).

boundary are summarized below. All sediments recovered below Cores 577-6 and 577A- 6 are barren of radiolarians and diatoms (Morley, this volume; Koizumi and Tanimura, this volume).

\section{Nannofossils}

The Upper Cretaceous (Maestrichtian) section at Site 577 is characterized by a rich nannofossil assemblage. The Micula prinsii, M. murus, and Lithraphidites quadratus zones were recognized, the latter penetrated only at Hole 577A (Fig. 2). Preservation of Cretaceous nannofossils is moderate and becomes poor in the very early Paleogene; calcareous nannofossils are considerably overgrown near the Cretaceous/Tertiary boundary. No significant changes in relative abundances of the Cretaceous taxa were observed from the $L$. quadratus Zone up to the boundary.

The Cretaceous/Tertiary boundary is located at Sample $577-12-5,130 \mathrm{~cm}$, Sample $577 \mathrm{~A}-12-4,72 \mathrm{~cm}$, and Sample 577B-1-4, $72 \mathrm{~cm}$ (Fig. 2). The boundary is defined in terms of calcareous nannofossils by the first occurrence of Thoracosphaera, a calcareous dinoflagellate, which occurs just at the bottom of the lithologic color change that marks the boundary. The rapid increase in frequency of Thoracosphaera occurs simultaneously with the first occurrence of small Biscutum such as B. romeinii and the extinction of most Mesozoic nannofossils. At Site 577, rare species of Thoracosphaera appear sporadically in the topmost Upper Cretaceous samples, about $5 \mathrm{~cm}$ below the Cretaceous/Tertiary boundary. Almost complete substitution (90-95\%) of the Mesozoic forms by Tertiary ones occurs about $10 \mathrm{~cm}$ above the Cretaceous/Tertiary boundary. In this interval, the assemblage is characterized by Thoracosphaera, small Biscutum, and foraminiferal debris.

The Paleogene Cruciplacolithus primus (CP1a) and the $C$. tenuis $(\mathrm{CP} 1 \mathrm{~b})$ subzones are recognized at all three holes drilled at Site 577 (Fig. 2). Reworked Cretaceous nannofossils are rare in the upper part of the $C$. primus Subzone, but become more abundant downward and dominate the Tertiary species in the samples just above the Cretaceous/Tertiary boundary.

\section{Planktonic Foraminifers}

Only very preliminary results from shipboard study of foraminifers contained in core-catcher samples were available at the time of this writing (Site 577 chapter, this volume), and those results are not adequate to carefully characterize the Cretaceous/Tertiary boundary. The first occurrence of Globigerina eugubina is located at the Cretaceous/Tertiary boundary (Monechi et al., this volume). Common to abundant foraminifer fragments occur immediately below the appearance of Thoracosphaera, which is a characteristic feature of Cretaceous/ Tertiary boundary sequences (Monechi, this volume). These fragments decrease and almost disappear about $40 \mathrm{~cm}$ above the boundary.

\section{MAGNETOSTRATIGRAPHY OF THE CRETACEOUS/TERTIARY BOUNDARY}

Paleomagnetic results obtained from Holes 577 and $577 \mathrm{~A}$ are detailed in Bleil (this volume). Because mag- 
netic intensities of the Paleogene and Cretaceous section were near the noise level of the shipboard spinner magnetometer, the results summarized here are based entirely on shore-based study with a cryogenic magnetometer. These results are synthesized with Site 577 calcareous nannofossil stratigraphic results and compared with results from other marine sections and DSDP data sets from recent South Atlantic legs in Monechi et al. (this volume).

Biostratigraphic and stable-isotope stratigraphic control facilitated correlation of the downhole magnetic reversal patterns with the recently revised geomagnetic polarity time scale of Berggren et al. (in press). Virtually complete reversal sequences were identified ending in the latest Cretaceous C-30N subchron and C-31N subchron at Holes 577 and 577A, respectively. In the vicinity of the Cretaceous/Tertiary boundary, the C-27N normal polarity subchron could not be recognized in Hole 577 (Fig. 2), presumably because of loss of material between Cores 577-11 and -12 or drilling disturbance in Core 577-11.

The Cretaceous/Tertiary boundary in both Holes 577 and $577 \mathrm{~A}$ is located within the C-29R subchron, the interval of reversed polarity that separates marine magnetic Anomalies 29 and 30 (Fig. 2), and is expanded relative to the preceding $\mathrm{C}-30 \mathrm{~N}$ and the following C-29N normal polarity subchrons. These results are in agreement with those obtained at various other marine sections (Alvarez et al., 1977; Alvarez and Lowrie, 1978; Hsü et al., 1982; Shackleton et al., in press; Thierstein, 1982). A numerical age determined for the Cretaceous/ Tertiary boundary by interpolation from the magnetic C-29R boundaries and by extrapolating downward using the $\mathrm{C} 29-\mathrm{N}$ and upward using the $\mathrm{C}-30 \mathrm{~N}$ boundaries varies between about 66.3 and 66.5 m.y., in agreement with other recent estimates using the same time scale (Berggren et al., in press; Shackleton et al., in press).

Based on paleomagnetic results, average sedimentation rates during the Late Cretaceous were $4.8 \mathrm{~m} / \mathrm{m}$.y. The sedimentation rate increased to about $7.6 \mathrm{~m} / \mathrm{m}$.y. in the Hole 577 and 577A C-29R subchrons that contain the Cretaceous/Tertiary boundary. Paleocene sedimentation rates averaged about $3 \mathrm{~m} / \mathrm{m}$.y.

\section{IRIDIUM ANOMALY AT THE CRETACEOUS/TERTIARY BOUNDARY}

Samples from Hole 577B were collected to measure iridium levels across the Cretaceous/Tertiary boundary by neutron-activation analysis. The sampling, analysis methods, and detailed results are given in Michel et al. (this volume). A major $\mathrm{Ir}$ anomaly of $61 \mathrm{ng} / \mathrm{cm}^{2}$ occurs at the same level as the Cretaceous/Tertiary boundary defined biostratigraphically by nannofossils (Fig. 2), comparable to the average anomaly $\left(50 \mathrm{ng} / \mathrm{cm}^{2}\right)$ observed at other Cretaceous/Tertiary boundaries (Alvarez et al., 1982).

Five smaller anomalies occur at Sample 577B-1-5, 120-121 cm, Sample 577B-1-4, 110-111 cm, Sample 577B-1-4, 81-83 cm, Sample 577B-1-4, 77-78 cm, and Samples 577B-1-1, $10 \mathrm{~cm}$ to 577B-1-2, $121 \mathrm{~cm}$ (Fig. 2; see also fig. 1 of Michel et al., this volume). The two smaller anomaly peaks observed in Section 5 and Sec- tions 1 through 2 are probably related to changes in the $\mathrm{CaCO}_{3}$ deposition rate; the two peaks closest to the main peak may be perturbations of that peak possibly caused by bioturbation; the final small peak in Section 4 remains unexplained, although it may have resulted from contamination of the samples or another extraterrestrial impact (Davis et al., 1984; Whitmire and Jackson, 1984). Resampling of the Cretaceous/Tertiary boundary interval is necessary to differentiate between these possibilities.

\section{OXYGEN- AND CARBON-ISOTOPE RESULTS}

Oxygen- and carbon-isotope data from Site 577 are available from two sources: (1) bulk fraction oxygenand carbon-isotope data from the Paleocene section above the Cretaceous/Tertiary boundary in both Holes 577 and $577 \mathrm{~A}$ in Shackleton et al. (this volume) and (2) Hole 577 fine fraction and benthic foraminifer oxygenand carbon-isotope data across the Cretaceous/Tertiary boundary in Zachos et al. (this volume).

Although the Shackleton et al. study was originally undertaken to examine the anomalously positive Paleocene ${ }^{13} \mathrm{C}$ event, the detailed carbon-isotope stratigraphy obtained proved useful in making accurate stratigraphic correlations between Holes 577 and 577A. Comparison of carbon-isotope, nannofossil, and paleomagnetic stratigraphies at Holes 577 and $577 \mathrm{~A}$ allowed adjustment of the sub-bottom depths of the top and bottom of the cored intervals, so that the adjusted depths of these data agree between both holes. Depths plotted in Figure 2 are drilled (unadjusted) depths; control points for adjusting core depths are given in Shackleton et al. (this volume) and may be useful in plotting results from future Site 577 studies.

The Shackleton et al. study suggests that the ${ }^{13} \mathrm{C} \mathrm{Pa}$ leocene event may represent compensation for the global extinctions and drop in productivity observed at the Cretaceous/Tertiary boundary, because these led to an increased nutrient level in the oceans and burial rate of organic matter. In addition, close similarity between the carbon-isotope records at Sites 577 and 527 (South Atlantic Ocean) suggests that it may be possible to develop a standard ${ }^{13} \mathrm{C}$ record for the Cenozoic that would have worldwide stratigraphic value, perhaps with a resolution better than that available from biostratigraphic methods.

The high-resolution stable-isotope and geochemical study completed by Zachos et al. (this volume) across the Cretaceous/Tertiary boundary at Holes 577 and 47.2 was aimed at evaluating changes in carbonate preservation affecting the stable-isotope signals from calcareous plankton and paleoceanographic changes that may have occurred at the boundary. Oxygen-isotope values of Hole 577 carbonate fine-fraction $(<63 \mu \mathrm{m})$ samples show only minor fluctuations in the Cretaceous Micula murus Zone averaging $-1.0 \pm 0.5 \%$, increase slightly near the Cretaceous/Tertiary boundary, and fluctuate between $-1.45 \%$ and $-0.16 \%$ in the early Paleocene Epoch (Fig. 2). This relatively minor enrichment of ${ }^{18} \mathrm{O}$ at the Cretaceous/Tertiary boundary may be a result of improved microfaunal preservation rather than a decrease in surface water temperature; even if the enrichment is a result of a temperature decrease in the North Pacific 


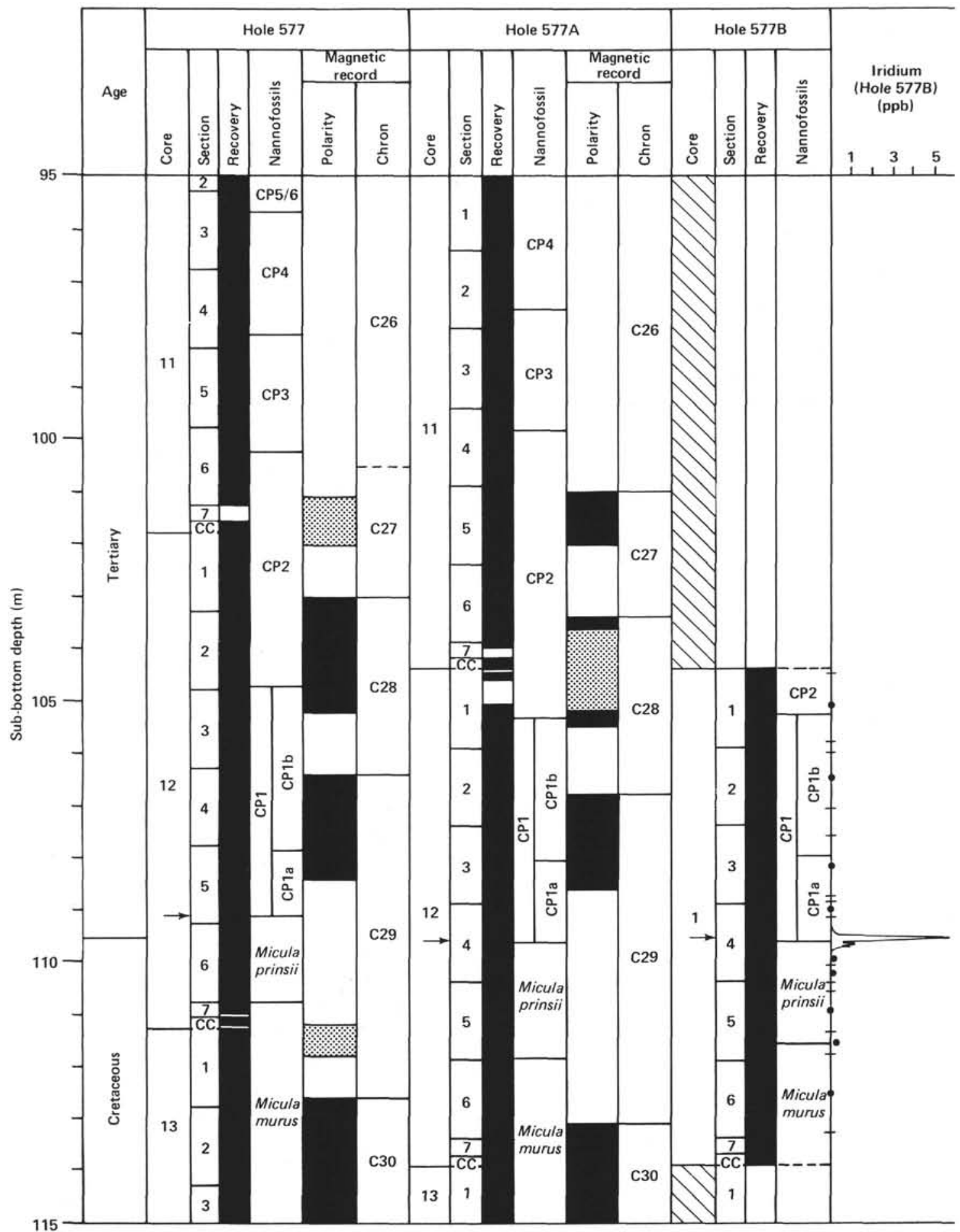

Figure 2. Summary diagram of Hole 577, 577A, and 577B age, cores, recovery, nannofossil stratigraphy, magnetostratigraphy, iridium, bulk fraction and fine fraction ${ }^{18} \mathrm{O}$ and ${ }^{13} \mathrm{C}$ stable isotopes, calcium-carbonate percentages, and lipid geochemistry data versus sub-bottom depth near the Cretaceous/Tertiary boundary (95-115 m sub-bottom). All data are plotted versus unadjusted depths (see Shackleton et al., this volume for adjusted depth explanation and control points). Dotted areas in magnetic record refer to gaps in the sample record (Monechi et al., this volume). Nannofossil stratigraphy is from Monechi (this volume). Magnetostratigraphy is given in Bleil (this volume) and Monechi et al. (this volume). Iridium data are from Michel et al. (this volume). Bulk-fraction stable-isotope data are from Shackleton et al. (this volume); fine-fraction stable-isotope data are from Zachos et al. (this volume). Calcium-carbonate contents are from shipboard carbonate-bomb results (see Site 577 chapter, this volume) and from Zachos et al. (this volume). Hole 577 lipid geochemical results are from Simoneit and Beller (this volume). Arrows in the core columns indicate locations of the Cretaceous/Tertiary boundary (Sample 577-12-5, $130 \mathrm{~cm}$, Sample 577A-12-4, $72 \mathrm{~cm}$, and Sample 577B-1-4, $72 \mathrm{~cm}$ ). 


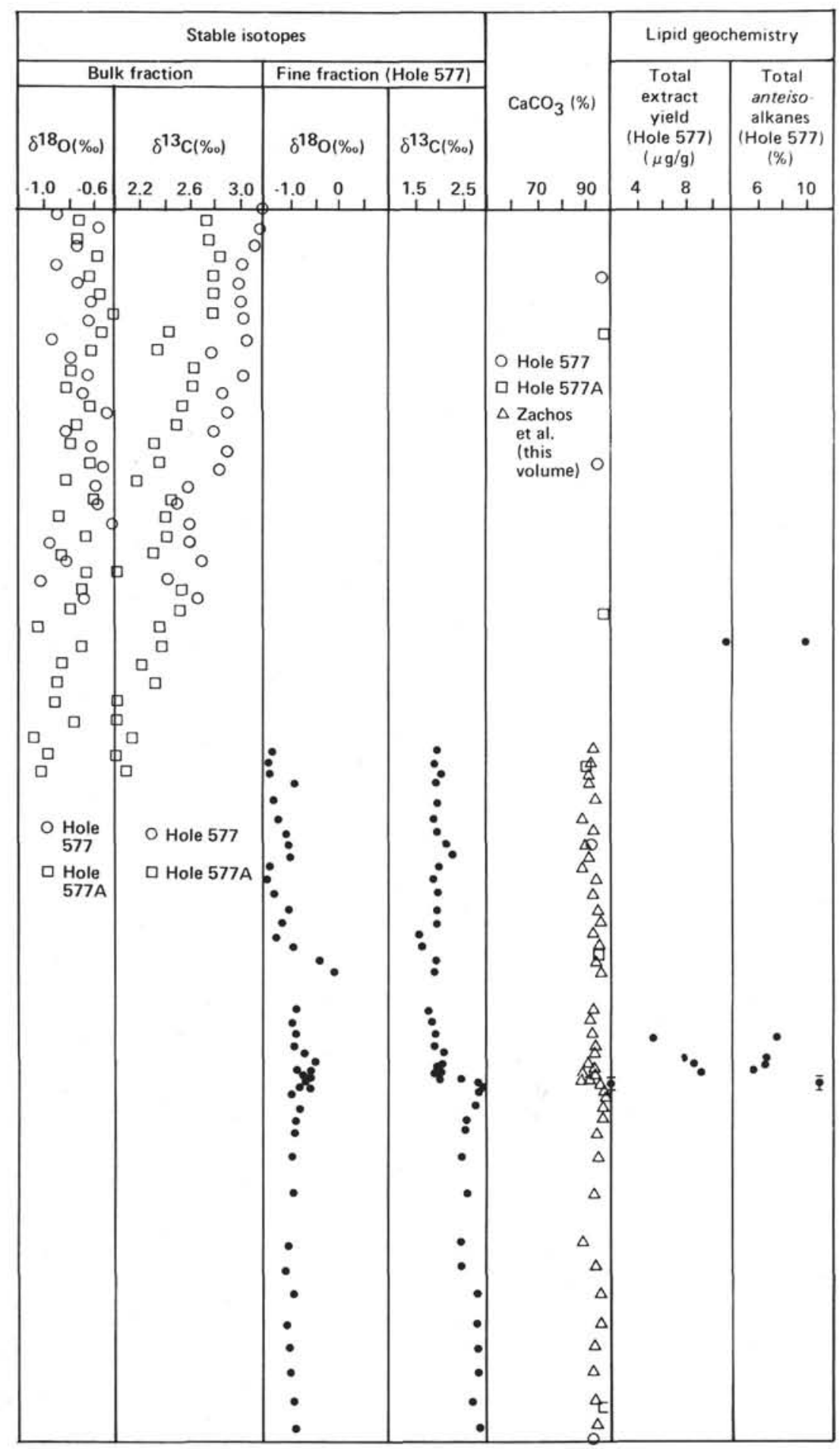

Figure 2. (Continued).

from Cretaceous to Tertiary time, the data suggest a $2^{\circ} \mathrm{C}$ temperature decrease at most.

Carbonate fine-fraction ${ }^{13} \mathrm{C}$ results indicate relatively constant values for the $M$. murus Zone, averaging $2.65 \pm 0.2 \%$. There is an abrupt decrease of $1.0 \%$ over a 10-cm interval at the Cretaceous/Tertiary boundary, coinciding with an interval of slightly lower carbonate content (Fig. 2). ${ }^{13} \mathrm{C}$ values remain relatively low throughout the measured Paleocene samples, between 1.7 and $2.3 \%$.
The negative ${ }^{13} \mathrm{C}$ shift observed at the Hole 577 Cretaceous/Tertiary boundary has been found in varying magnitudes at nearly every Cretaceous/Tertiary boundary sequence studied, suggesting that, barring significant hiatuses, this shift is an excellent stratigraphic marker for the boundary. The ${ }^{13} \mathrm{C}$ shift is interpreted to represent an abrupt decrease in oceanic surface water productivity associated with the Cretaceous/Tertiary extinction event. This interpretation is supported by the observed reduc- 
tion of total carbonate accumulation rates from an average $1.10 \mathrm{~g} / \mathrm{cm}^{2} / 1000 \mathrm{yr}$. during the Maestrichtian to $0.3 \mathrm{~g} / \mathrm{cm}^{2} / 1000 \mathrm{yr}$. immediately above the Cretaceous/ Tertiary boundary with no apparent changes in carbonate preservation (see table 4 and fig. 8 in Zachos et al., this volume). ${ }^{13} \mathrm{C}$-isotopic gradients derived by comparing planktonic fine-fraction data and benthic data suggest that primary productivity recovered to pre-Cretaceous/Tertiary boundary levels by $2 \mathrm{~m}$.y. following the extinction event.

\section{LIPID GEOCHEMISTRY ACROSS THE CRETACEOUS/TERTIARY BOUNDARY}

Six samples from above and just below the Cretaceous/Tertiary boundary at Hole 577 were analyzed by gas chromatography and gas chromatography-mass spectrometry to look for geochemical evidence of the mass extinctions and faunal successions characteristic of this period (Simoneit and Beller, this volume). Lipid compositions of all these samples are very similar, but the yields may indicate a trend at the Cretaceous/Tertiary boundary (Fig. 2). Trace molecular markers indicate an algal and, above the Cretaceous/Tertiary boundary, possibly a terrestrial resinous plant component. Definitive assignment of the original lipid sources of these samples is not possible since these residues are derived predominantly from bacteria, which efficiently metabolized the other lipids in an oxic depositional environment or at least oxidizing diagenetic conditions. Therefore, molecular stratigraphy cannot be applied definitely across the Cretaceous/Tertiary boundary at Site 577 with these limited samples.

\section{CONCLUSIONS}

Three continuous, expanded, and undisturbed Cretaceous/Tertiary boundary sequences were recovered at the three holes hydraulically piston cored at Site 577 on the
Shatsky Rise. Based on nannofossil biostratigraphy, the boundary is located at Sample $577-12-5,130 \mathrm{~cm}$, Sample $577 \mathrm{~A}-12-4,72 \mathrm{~cm}$, and Sample 577B-1-4, $72 \mathrm{~cm}$, within the magnetic C-29R subchron. At this same level, an iridium anomaly of $61 \mathrm{ng} / \mathrm{cm}^{2}$ and a sharp decrease of $1.0 \%{ }^{13} \mathrm{C}$ were observed. These results are characteristic of other marine Cretaceous/Tertiary boundary sections and add support to the extraterrestrial-impact theory offered as explanation for the microfaunal and microfloral extinctions observed at the boundary.

\section{REFERENCES}

Alvarez, W., Alvarez, L. W., Asaro, F., and Michel, H. V., 1982. Current status of the impact theory for the terminal Cretaceous extinction. Geol. Soc. Am. Spec. Pap., 190:305-315.

Alvarez, W., Arthur, M. S., Fischer, A. F., Lowrie, W., Napoleone, G., Premoli Silva, I., and Roggenthen, W. M., 1977. Type section for the Late Cretaceous-Paleocene geomagnetic reversal time scale. Geol. Soc. Am. Bull., 88:383-389.

Alvarez, W., and Lowrie, W., 1978. Upper Cretaceous paleomagnetic stratigraphy at Moria (Umbrian Apennines, Italy): verification of the Gubbio section. Geophys. J. R. Astron. Soc., 55:1-17.

Berggren, W. A., Kent, D. V., and Flynn, J. J., in press. Paleogene geochronology and chronostratigraphy. In Snelling, N. J. (Ed.), Geochronology and the Geological Record. Geol. Soc. London Special Paper.

Davis, M., Hut, P., and Muller, R. A., 1984. Extinctions of species by periodic comet showers. Nature (London), 308:715-717.

Hsü, K. J., He, Q., McKenzie, J. A., Weissert, H., Perch-Nielsen, K., et al., 1982. Mass mortality and its environmental and evolutionary consequences. Science, 216:249-256.

Shackleton, N. J., and Shipboard Scientific Party, 1984. Accumulation rates in Leg 74 sediments. In Moore, T. C., Jr., Rabinowitz, P. D., et al., Init. Repts. DSDP, 74: Washington (U.S. Govt. Printing Office), 621-644.

Thierstein, H. R., 1982. Terminal Cretaceous plankton extinction: a critical assessment. Geol. Soc. Am. Spec. Pap., 190:385-399.

Whitmire, D. P., and Jackson, A. A., IV, 1984. Are periodic mass extinctions driven by a distant solar companion? Nature (London), 308:713-715.

Date of Initial Receipt: 9 January 1985

Date of Acceptance: 6 February 1985 